\title{
Food and Feeding Habits of Catfish Clarias Batrachus (Linn) in Bhadravathi Area, Karnataka
}

\author{
I.Ramesh*, B. R. Kiran ** \\ *Department of Zoology, Government Science College, Chitradurga, Karnataka \\ **Research \& Teaching Assistant in Environmental Science, DDE, Kuvempu University, \\ Shankaraghatta, Karnataka
}

\begin{abstract}
The pattern of food and feeding habits of cat fish, Clarias batrachus were studied during the period January to June 2009. Fish species were procured from fishermen every month using gill nets and cast nets of various sizes. A total of 30 specimens were examined. The food analysis of Clarias batrachus revealed that the food consisted of zooplankton, insect larvae, fish larvae, small shrimps and organic debris. Fish larvae and insect larvae were preferred as the major food item in all the months. On average for all months of the study period, insect larvae dominated the list with 31.08\%.The other food items in the descending order are fish larvae (25.61\%), worms (19.78\%), small shrimps (17.0\%), organic debris (4.48\%) and zooplankton (2.03\%). The feeding intensity is poorer from pre-spawning and spawning period but remarkably higher from postspawning period. The type of food items recorded from the guts indicated that the fish is a column to bottom feeder almost of the food items were bottom dwelling organisms and is predominantly a carnivorous fish.
\end{abstract}

Keywords: Food and feeding, Clarias batrachus, catfish, Bhadravathi, India

\section{INTRODUCTION}

The catfish Clarias batrachus is a species of freshwater air breathing catfish native to Southeast Asia, but also introduced outside its native range where it is considered an invasive species.It is named for its ability to "walk" across dry land, to find food or suitable environments. While it does not truly walk as most bipeds or quadrupeds do, it has the ability to use its pectoral fins to keep it upright as it makes a sort of wiggling motion with snakelike movements("Catfish 'walk' down street".Metro.co.uk.200807-18). This fish normally lives in slow-moving and often stagnant waters in ponds, swamps, streams and rivers, flooded rice paddies or temporary pools which may dry up. When this happens, its "walking" skill allows the fish to move to other sources of water. Considerable taxonomic confusion surrounds this species and it has frequently been confused with other close relatives (Froese, Rainer and Pauly, Daniel, eds, 2011; Ng, Heok Hee, and Kottelat, Maurice , 2008; https://en.wikipedia.org).

It contains higher percentage of protein and iron as compared to other edible freshwater fish species (Sakhare 2012). Its fat content is also very low and is therefore easily digestible so that it is very useful during convalescence. With most other it is a delicacy because of the characteristic aroma and softness of its flesh. Food and feeding habits of fishes have been a field of interest to fisheries researchers since very long (Sakhare and Chalak, 2014). Sakhare (2010) studied food and feeding of Cyprinus carpio from local markets, reservoirs and ponds around Ambajogai. Arthi et al.(2011) conducted the study on food and feeding habits of Ompak bimaculatus and O. malabaricus of river Amaravathy in Tamil Nadu and reported both fishes as omnivorous, feeding mainly on vegetable matter and fish.

Despite of all this, there is no scientific literature on food and feeding habits of C. batrachus from Malnad region of Karnataka. Hence, the present study was carried out.

\section{Materials AND Methods}

A total of 30 specimens were collected from local market of Bhadravathi town (Latitude $13^{\circ} 52^{\prime} \mathrm{N}$ and Longitude $75^{\circ} 40^{\prime} \mathrm{E}$ ), Shimoga district, Karnataka for six months beginning from January to June 2009 and analyzed for food and feeding habits. Total body length and weight were taken. The total lengths of the fish were recorded to the nearest millimeter from the tip of the snout to the tip of the 
caudal fin. Weights of fish were recorded to the nearest gram with the help of electronic weighing balance. The specimens were preserved in $10 \%$ formaldehyde immediately after the collection and were brought to the laboratory for further analysis. After taking the length and weight the entire gut was taken and for the analysis of the different food items.

\subsection{Food and Feeding Habits}

Both qualitative and quantitative analysis were carried out to study the stomach contents of Clarias batrachus. Gravimetric method (Hynes 1950) was used for the percentage composition of different food items.

Each gut was emptied in a petridish and the contents observed under binocular microscope. For qualitative analysis, the identification of different food items was made up to the generic level.

\subsection{Quantitative Analysis}

The stomach contents were washed into a petridish and points were given depending on the relative volume of each food item taking into consideration the extent of fullness of stomach and the amount of food contained. In the present study, the fullness of the stomach was classified as (i) gorged (The stomach swollen with food, the cardiac part being well expanded to a maximum size); (ii) full; (iii) $3 / 4$ full; (iv) $1 / 2$ full; (v) $1 / 4$ full; (vi) little; and (vii) empty based on the intensity of feeding and the degree of distention of the stomach.

\section{RESUlTS AND DisCUSSION}

The food analysis of 30 specimens of C.batrachus collected from different water bodies around Bhadravathi area revealed that the food consisted of insect larvae, fish larva, zooplankton, shrimps and organic debris. From Figure1 it can be observed that in C. batrachus fish larvae and insect larvae were preferred as the primary food item in all the months. On average for all months of the study period, insect larvae dominated with a percentage of $31.08 \%$ and the other food items in descending order are fish larvae (25.61\%), worms(19.78\%), small shrimps (17.0\%), organic debris $(4.48 \%)$ and zooplankton $(2.03 \%)$ (Figure2). The preference of food items are in the following order

Insect larvae $>$ Fish larvae $>$ Worms $>$ Small shrimps $>$ Organic Debris $>$ Zooplankton

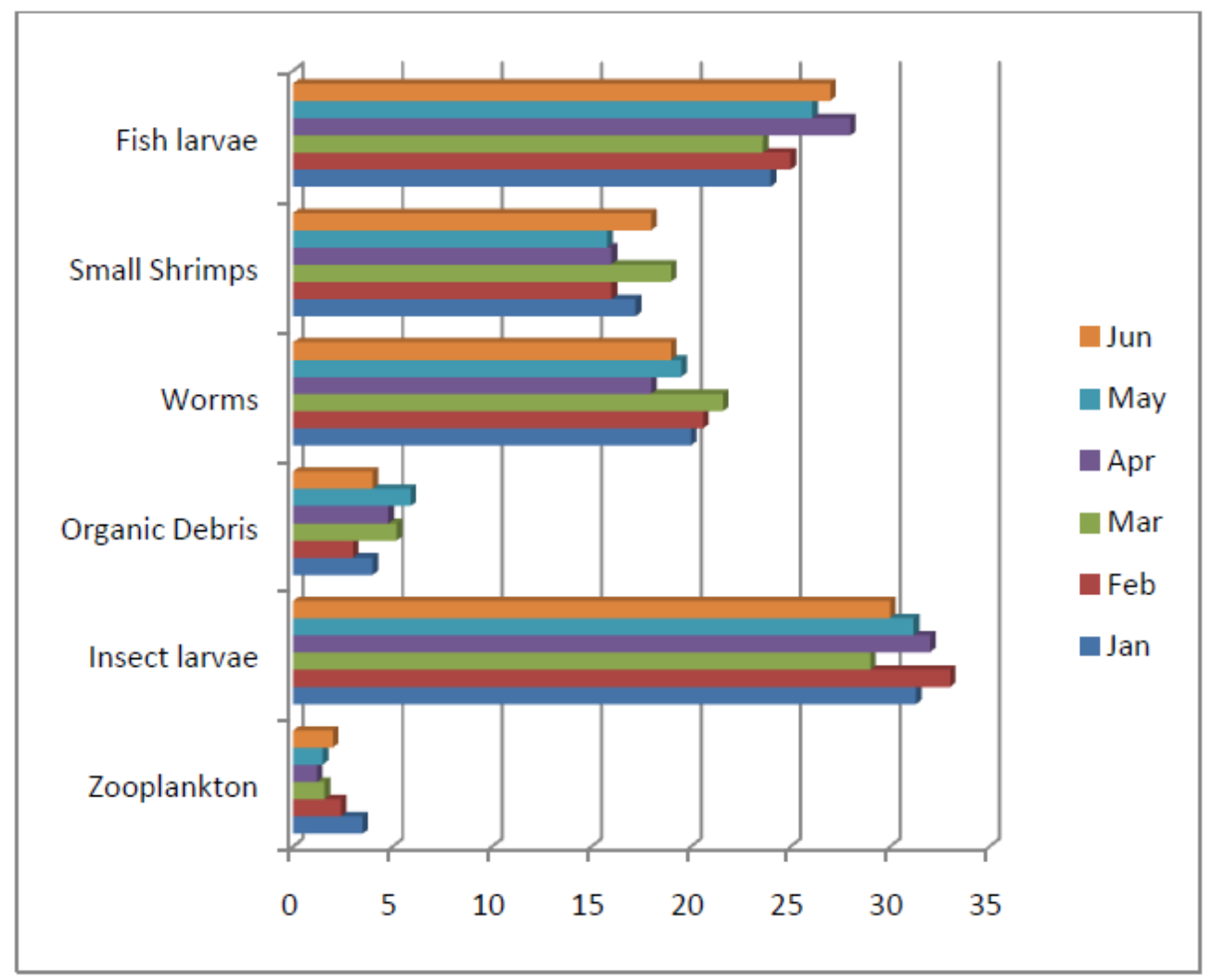

Figure1. Percentage occurrence of food items in relation to different months of Clarias batrachus 


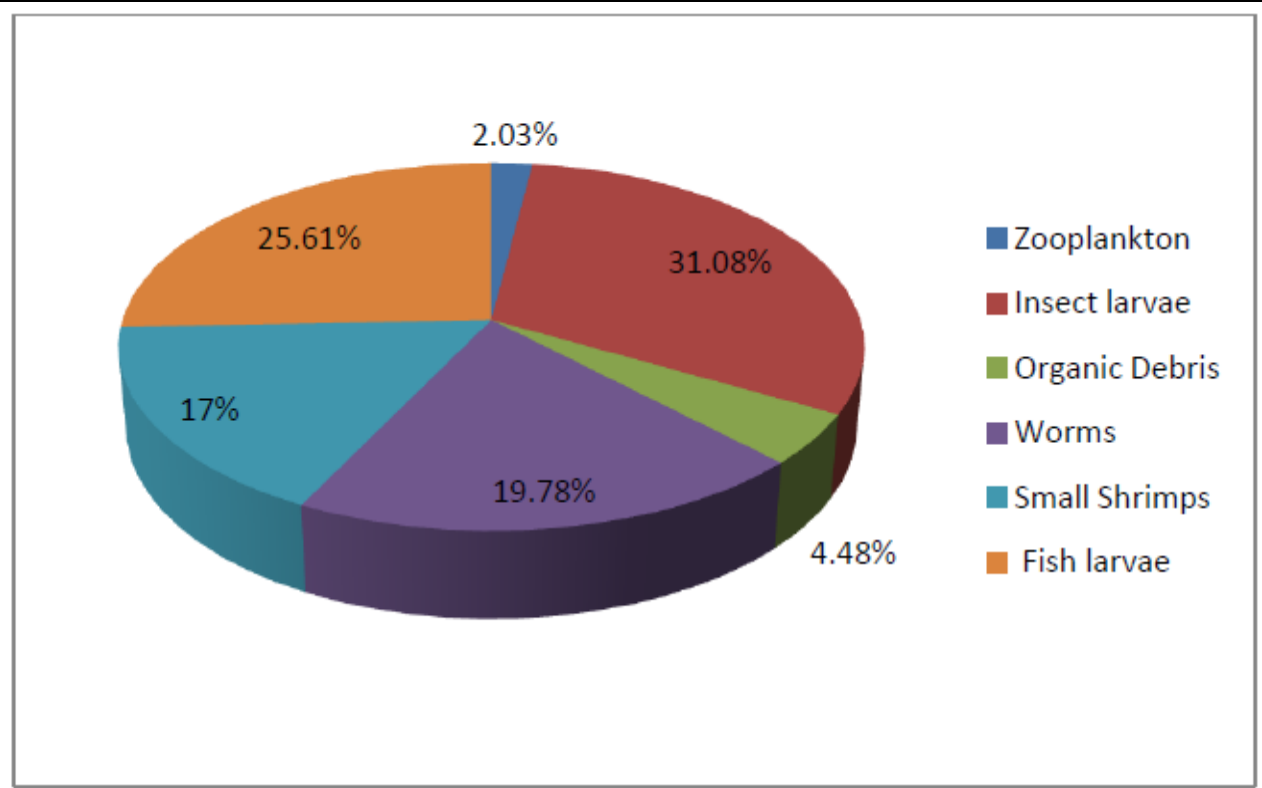

Figure2. Percentage composition of various food items of Clarias batrachus

In the present investigation, the poor feeding activities in case mature fishes coincides with the peak spawning season. Bhuiyan et al.(2006) reported very poor feeding intensity in mature species of Channa punctatus during May to July. Saikia et al. (2012) also reported low feeding intensity of Channa punctatus in June-J uly and November-January. Basudha and Vishwanath (1999) observed low feeding intensity in Ostebrama belangiri during June-August.

\subsection{Feeding Intensity}

The stomachs of fishes collected for the study of food and feeding habits were classified depending on their relative fullness into gorged, full, $3 / 4$ full, $1 / 2$ full, $1 / 4$ full, little and empty. Fishes with stomachs classified as gorged, full, $3 / 4$ full, $1 / 2$ full were considered to have actively fed, whereas those with $1 / 4$ full and little as poorly fed. Data on the percentage occurrence of various degree of fullness of stomach is presented in Table1.

It has been observed that fishes collected from the fish market showed almost $60-80 \%$ of fishes have empty stomach (as Clarias being a live fish, selling of fish in the market usually takes place in live condition).The feeding intensity is lower from pre-spawning and spawning period but remarkably higher from post-spawning period.

Table1. Percentage index of fullness in the stomach of Clarias batrachus

\begin{tabular}{|l|c|c|c|c|c|c|}
\hline \multirow{2}{*}{$\begin{array}{c}\text { Condition } \\
\text { of } \text { stomach }\end{array}$} & \multicolumn{6}{c|}{ Months } \\
\cline { 2 - 7 } & JAN & FEB & MAR & APR & MAY & JUN \\
\hline Gorged & 0 & 0 & 0 & 0 & 0 & 1.33 \\
\hline Full & 5.50 & 0 & 0 & 0 & 5.88 & 4.65 \\
\hline 3/4 full & 0 & 0 & 0 & 0 & 2.06 & 0 \\
\hline $1 / 2$ full & 10.17 & 20.00 & 23.08 & 6.38 & 24.41 & 10.30 \\
\hline $1 / 4$ full & 12.20 & 11.12 & 7.70 & 4.26 & 17.60 & 11.63 \\
\hline Little & 6.58 & 0 & 0 & 2.13 & 10.05 & 0 \\
\hline Empty & 65.55 & 68.90 & 69.22 & 87.23 & 40.00 & 72.09 \\
\hline
\end{tabular}

\section{REFERENCES}

[1] Arthi T, Nagarajan S and Sivakumar A.A (2011) Food and feeding habits of two freshwater fishes, Ompak bimaculatus and O. malabaricus of river Amaravathy, Tamil Nadu. The Bioscan 6(3): 417-420.

[2] Basudha CH and Vishwanath W (1999) Food and feeding habits of an endemic carp, Osteobrama belangiri (Val) in Manipur. Indian Journal of Fisheries 46(1): 71-77.

[3] Bhuiyan AS, Afroz S and Zaman T (2006) Food and feeding habit of the juvenile and adult snakehead, Channa punctatus (Bloch). Journal of Life and Earth Science 1(2): 53-54.

[4] Catfish 'walk' down street. Metro.co.uk. 2008-07-18. Retrieved 2008-07-18. 
[5] Froese, Rainer and Pauly, Daniel, eds. (2011). "Clarias batrachus" in FishBase. December 2011 versio

[6] Hynes H.B.N (1950) the food of freshwater stickleback with a review of the methods used in studies of food of fishes. Journal of Animal Ecology 191: 36-58.

[7] $\mathrm{Ng}$, Heok Hee, and Kottelat,Maurice (2008). The identity of Clarias batrachus (Linnaeus, 1758), with the designation of a neotype (Teleostei: Clariidae). Zoological Journal of the Linnean Society $153:$ 725-732.

[8] Sakhare, V.B and Chalak ,A.D (2014) Food and feeding habits of Clarias batrachus (Linnaeus, 1758) from Ambajogai, Maharashtra, India. Journal of Fisheries 2(2):148-150. DOI: dx.doi.org/ 10.17017/jfish.v2i2.2014.33.

[9] Sakhare V.B (2012) Inland Fisheries, Daya Publishing House, New Delhi, India.

[10] Sakhare V.B (2010) Food and Feeding habit of common carp, Cyprinus carpio (Linn). Fishing Chimes 30(1): 180-182.

[11] Saikia AK, Abujam SKS and Biswas SP (2012) Food and feeding habit of Channa punctatus (Bloch from the paddy field of Sivasagar District, Assam. Bulletin of Environment, Pharmacology and Life Sciences 1(5): 10-15. 